\title{
The Effects of High-Grade Metamorphism on Cr-Spinel from the Archean Sittampundi Complex, South India
}

\author{
Davide Lenaz ${ }^{1, *(\mathbb{D})}$, Bidyananda Maibam ${ }^{2}$, Jacob Adetunji ${ }^{3}$ and Henrik Skogby $4, *$ (D) \\ 1 Department of Mathematics and Geosciences, University of Trieste, 34128 Trieste, Italy \\ 2 Department of Earth Sciences, Manipur University, Imphal 795003, India; bmaibam@yahoo.com \\ Department of Environmental Sciences, University of Derby, Derby DE22 1GB, UK; j.adetunji@derby.ac.uk \\ 4 Department of Geosciences, Swedish Museum of Natural History, SE-10405 Stockholm, Sweden \\ * Correspondence: lenaz@units.it (D.L.); henrik.skogby@nrm.se (H.S.)
}

Citation: Lenaz, D.; Maibam, B.;

Adetunji, J.; Skogby, H. The Effects of High-Grade Metamorphism on

Cr-Spinel from the Archean Sittampundi Complex, South India. Minerals 2021, 11, 1370. https:// doi.org/10.3390/min11121370

Academic Editor: Frederick Lin Sutherland

Received: 7 October 2021

Accepted: 30 November 2021

Published: 3 December 2021

Publisher's Note: MDPI stays neutral with regard to jurisdictional claims in published maps and institutional affiliations.

Copyright: (c) 2021 by the authors. Licensee MDPI, Basel, Switzerland. This article is an open access article distributed under the terms and conditions of the Creative Commons Attribution (CC BY) license (https:// creativecommons.org/licenses/by/ $4.0 /)$.

\begin{abstract}
We investigated the crystal and structural behavior of Cr-bearing spinels from the Archean chromitites of Sittampundi (India), which had been subjected to very high-grade metamorphism. The structural data show that their oxygen positional parameters are among the highest ever recorded for Cr-bearing spinels with similar Cr\# and Mg\# and very similar to those found for other Archean occurrences. The general agreement between electron microprobe and Mössbauer data indicates that the analyzed spinels are stoichiometric. It is therefore most likely that the $\mathrm{P}_{\mathrm{H}_{2} \mathrm{O}}$ and $\mathrm{P}_{\text {total }}$ values as well as both the oxygen fugacity and the temperature reached during high-grade metamorphism inhibited the possibility of the non-stoichiometry of chromites, contrary to what can happen in ophiolites, where non-stoichiometry has recently been documented.
\end{abstract}

Keywords: Cr-spinels; high-grade metamorphism; structural refinement; Mössbauer spectroscopy; Sittampundi; India

\section{Introduction}

The Neoarchaean Sittampundi Complex in southern India [1] is a metamorphosed anorthositic complex within the Palghat-Cauvery Suture Zone (PCSZ), preserving an original igneous stratigraphy, including chromitites overprinted by high-grade metamorphic assemblages [2-5] that, according to Sajiev et al. [6,7], could be retrograded from eclogite-facies assemblages.

Cr-spinel is useful as an indicator of the crystallization condition in a wide range of geological environments. It also records modifications induced during subsequent prograde or retrograde metamorphism of host rocks. The chemical durability of the chromite makes it useful as a petrogenetic indicator in ultramafic rocks in which metamorphic recrystallization has obliterated other primary fingerprints [8-10]. Changes in the composition and structure of chromite from ultramafic complexes during metamorphic modification have been studied by several researchers [11-14]. The relationships between compositional and structural parameters in natural $\mathrm{Cr}$-spinels have been considered by several authors, providing a new approach to the understanding of mechanisms of spinel crystallization in magmatic and metamorphic environments [15-23]. The intracrystalline distribution of cations in spinels is a function of the thermodynamic parameters, including temperature, pressure and composition. Natural samples exhibit a non-equilibrium distribution of cations that depends on the thermodynamic parameters controlling the equilibrium order and the pressure-temperature-time path the crystals experienced. The ordering process involves short-range diffusion of cations, along with the breaking of bonds and a large kinetic barrier [24]. The equilibrium temperature corresponding to the observed order of a sample is called its closure temperature, $T_{C}$ [25]; $T_{C}$ provides insight on (1) a lower limit of the maximum temperature that the rock experienced and (2) a comparative cooling rate. Although the geothermometer modelled by [26] is mainly used for Mg-Al 
spinels, [27] found out that is suitable for Cr-rich compositions as well. The commonly used intercrystalline thermometers are those by $[28,29]$, using olivine-Cr-spinel pairs, even if [30] showed that they do not always show an appropriate equilibration temperature.

In this study, we report the results of a structural-chemical investigation of chromite crystals extracted from the chromitite seams hosted by meta-anorthosite from the Sittampundi complex. We have taken up this work (a) to increase the database for $\mathrm{Cr}$-spinels in chromitites of high-alumina continental layered intrusions, as crystal-chemical studies on spinels from layered chromitites are limited to a few places only, such as the Bushveld, Stillwater, Rum and Amsaga complexes [31-34] and Fiskenæsset [35] and (b) to verify whether relationships exist between the structural and compositional parameters of the spinels and a high grade of metamorphism of the chromitites.

\section{Geology and Petrography}

The Sittampundi complex belongs to the metamorphosed Archean layered anorthosite complex. The study area forms a part of the granulite terrane of south India. Major rock types are chromitite-bearing meta-anorthosite, amphibolite, basic granulite, two-pyroxene granulite, leptynite, biotite gneiss and pink granite. Subramanian [2] carried out a detail systematic study of the Sittampundi complex (Figure 1).

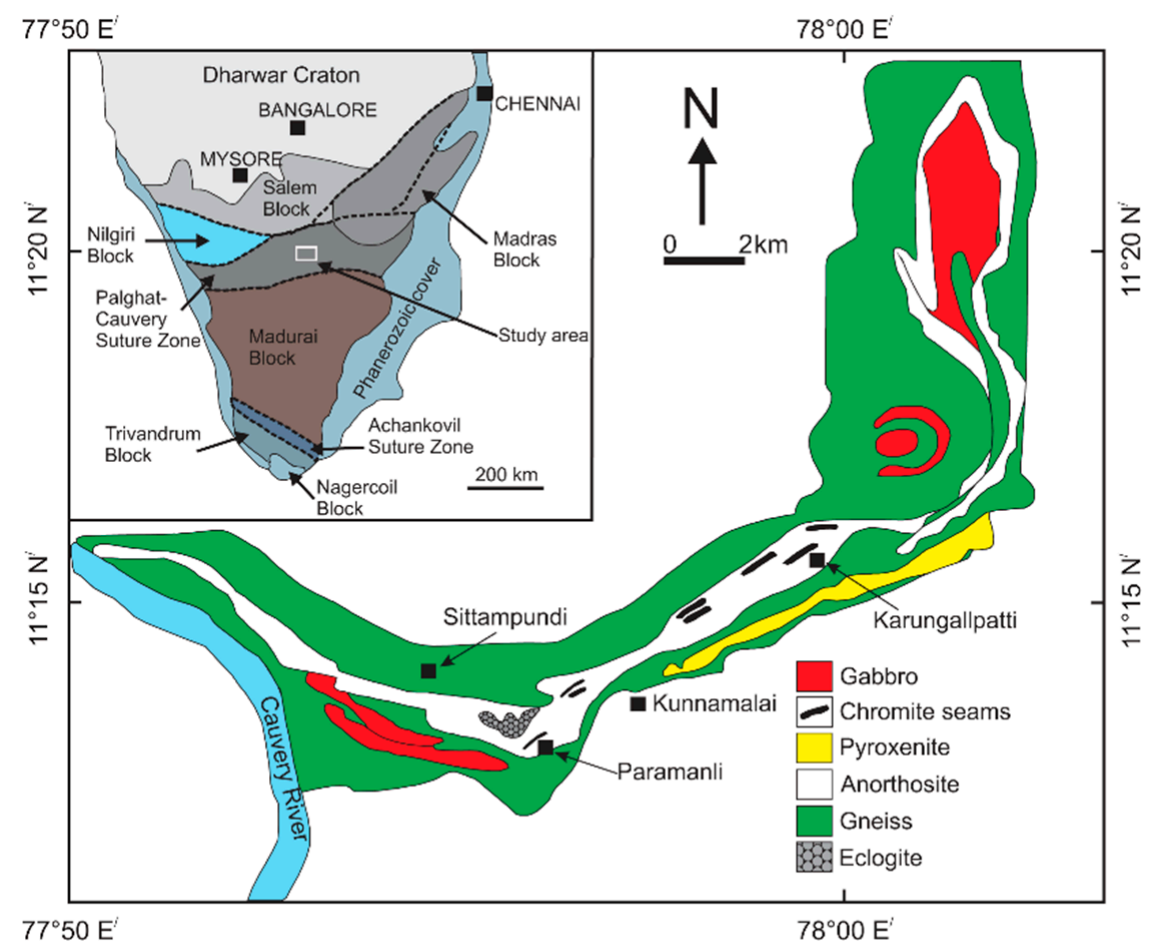

Figure 1. Geological map of the Sittampundi Complex. Modified from [2,36].

Sajeev et al. [6] reported retrogressed eclogite within the orthopyroxene free metagabbro, with the garnet of the rock hosting needles of rutile and omphacite. They suggested the assemblage as the peak eclogite facies condition of the rock. However, several authors have suggested that the high-grade metamorphism of the Sittampundi complex culminated at 11-12 Kbar pressure and $700-800{ }^{\circ} \mathrm{C}$ [37-39]. The peak metamorphic conditions were later overprinted by fluid influx and decompression-related retrograde a ssemblages. Although there is local preservation of primary igneous textures, almost all the primary minerals recrystallized during the high-grade metamorphism and obliterated the igneous textures and minerals. Felsic magma intruded the Sittampundi layered Complex at about $2.51 \mathrm{Ga}$, and, successively, the rock sequence underwent granulite facies (2450-2500 Ma) and amphibolite facies (500-720 Ma) metamorphism. The amphibolite facies metamorphism caused the modification of some chromites to $\mathrm{Cr}$-poor green spinel [40]. Chromitite 
occurs exclusively within meta-anorthosite as discontinuous layered bands/lenses of varying thickness, with a maximum of $5 \mathrm{~m}$ within anorthosites and consisting of more than $60 \%$ chromite grains.

Earlier workers reported that the chromitites contain FeAl-rich chromites concentrated in layers between amphibole-rich layers, with a dominant mineralogy of amphibole spinel - plagioclase \pm sapphirine $[7,36,41]$. These authors suggested the existence of original highly calcic plagioclase ( $>\mathrm{An}_{95}$ ), FeAl-rich chromite and magmatic amphibole, which are consistent with a derivation from a parental magma of hydrous tholeiitic composition.

Samples used for crystal-chemical investigation were culled from chromitites (chromite + rutile + calcic amphibole \pm anthophyllite \pm clinochlore). The samples studied were collected from conformable chromitite lenses within meta-anorthosite (Figure 2a) on a foot track in the western part of Karungalpatti, Salem District, Tamil Nadu.
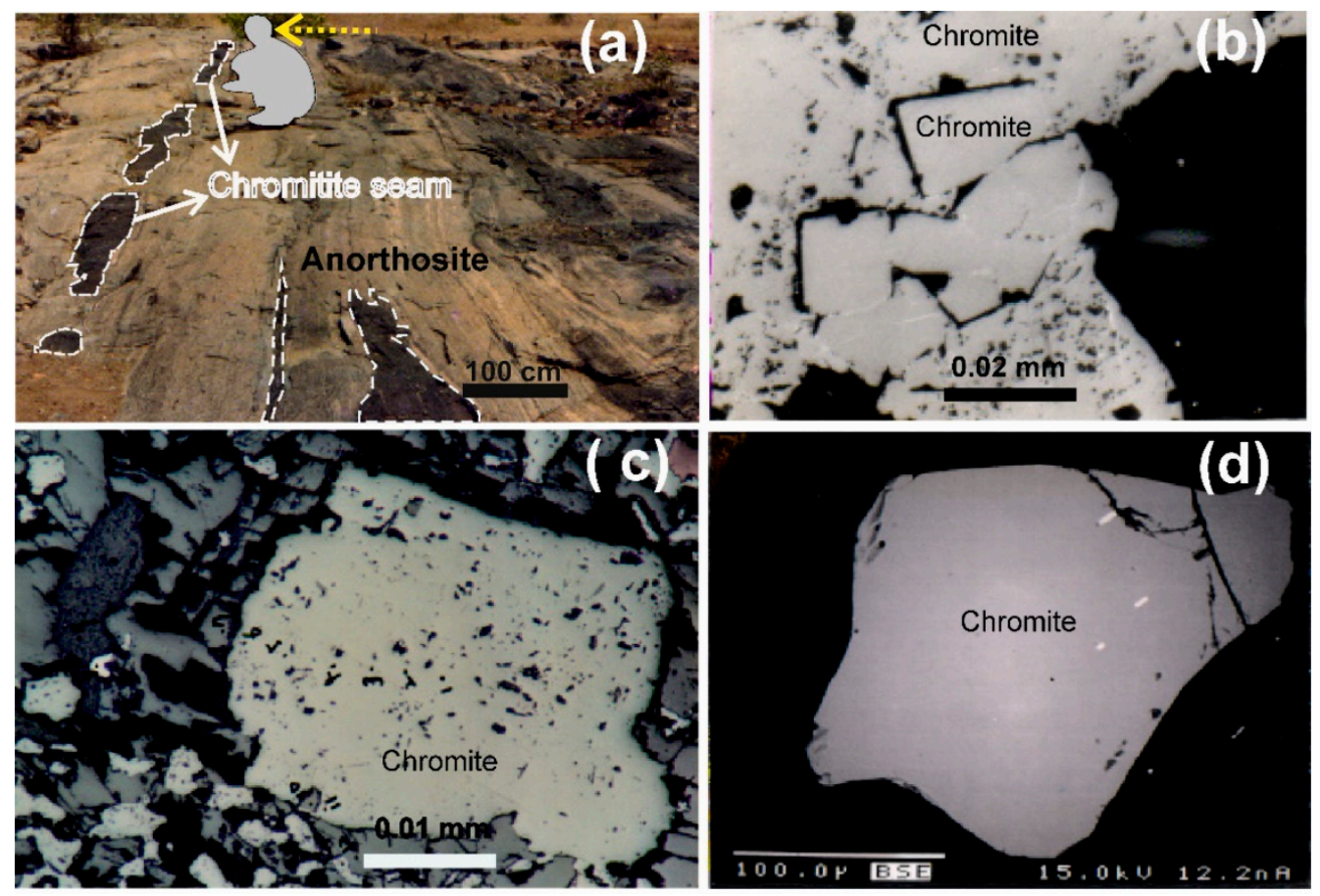

Figure 2. (a) Field photograph of discontinuous chromite seam hosted by meta-anorthosite. Person is for reference; (b) photomicrograph of polygonal faceted chromite grains within non-porous chromite; (c) chromite grains with silicate inclusions surrounded by intercumulus amphiboles; (d) back-scattered electron image of a representative chromite grain; exsolved rutile needles are seen as white needles.

According to [40], chromite compositions in Sittampundi show large variations in their chemical parameters, such as $\mathrm{Cr} /(\mathrm{Cr}+\mathrm{Al})(\mathrm{Cr} \#=0.26-0.60), \mathrm{Mg} /\left(\mathrm{Mg}+\mathrm{Fe}^{2+}\right)(\mathrm{Mg} \#=0.40-0.45)$ and $\mathrm{Fe}^{3+} /\left(\mathrm{Fe}^{3+}+\mathrm{Al}+\mathrm{Cr}\right)\left(\mathrm{Fe}^{3+} \#=0.20-0.24\right)$, depending on textural type and nature of the associated phases, and occur within discontinuous bands within clinopyroxenite and highly calcic anorthosite. Previous Mössbauer studies on some chromites from Sittampundi, developed by [42], show that $\mathrm{Fe}^{2+}$ and $\mathrm{Fe}^{3+}$ occur at both tetrahedral and octahedral sites and that the $\mathrm{Fe}^{3+} / \Sigma \mathrm{Fe}$ ratio is in the range $0.45-0.48$. The oxygen positional parameters reported in that paper, calculated through chemical and Mössbauer analyses, are 0.2561 and 0.2603 . While the first one is rather unreliable, being very similar to those of completely inverted spinels such as magnetite, the second value is rather close to that of 0.2607 recorded in an oxidized Cr-spinel recovered from a terra rossa soil [43]. Another study on Cr-spinel from Sittampundi is the one by [44], which, following those of [45-47] among the others, studied the Raman shifts of these samples.

Chromite occurs as granular aggregates in close association with amphiboles in the meta-anorthosite hosted chromitites. The rock shows a schistose texture, displaying the pre- 
ferred orientation of amphiboles. Chromite, amphibole, chlorite and plagioclase form the major components. Chromite is also present as inclusions within the amphibole (Figure 2c). Chromite abundance is between $40 \%$ and $75 \%$ in the studied samples. The original igneous texture of the chromitite, such as chromite cumulate texture, igneous layering, etc., is preserved. The chromite grains are euhedral to subhedral (Figure 2c,d). Euhedral chromite grains are in common with well-defined grain boundaries and fracture zones. Some chromite grains of pseudohexagonal grain boundaries indicate their recrystallization (Figure 2b).

\section{Materials and Methods}

\subsection{X-ray Single Crystal Diffraction}

In total, four $\mathrm{Cr}$-spinels have been analyzed by means of X-ray single crystal diffraction and electron microprobe. X-ray diffraction data were recorded on an automated KUMAKM4 (K-geometry) diffractometer (KUMA, Wroclaw, Poland), using MoK $\alpha$ radiation, monochromatized by a flat graphite crystal. Data were collected, according to [48], with up to $55^{\circ}$ of $2 \theta$ in the $\omega-2 \theta$ scan mode (scan width $1.8^{\circ} 2 \theta$, counting times from 20 to $50 \mathrm{~s}$, depending on the peak standard deviation). Twenty-four equivalent reflections of $(12,8,4)$, at about $80^{\circ}$ of $2 \theta$ were accurately centered at both sides of $2 \theta$, and the $\alpha 1$ peak barycenter was used for cell parameter determination. Structural refinement using the SHELX-97 program [49] was carried out against $F^{2}{ }_{h k l}$ in the $F d-3 m$ space group (with the origin at $-3 \mathrm{~m}$ ), since no evidence for different symmetry appeared. Scattering factors were taken from $[50,51]$. The crystallographic data are presented in Table 1.

\subsection{Electron Microprobe Analysis}

Ten to fifteen spot analyses were performed on the same $\mathrm{Cr}$-spinels used for X-ray data collection, using a CAMECA-SX50 electron microprobe (EPMA) (CAMECA, Gennevilliers Cedex, France) at IGG-CNR (Istituto di Geoscienze e Georisorse-Consiglio Nazionale delle Ricerche, Padua, Italy), operating at $15 \mathrm{kV}$ and $15 \mathrm{nA}$. A $20 \mathrm{~s}$ counting time was used for both peak and total background. Synthetic $\mathrm{MgCr}_{2} \mathrm{O}_{4}$ and $\mathrm{FeCr}_{2} \mathrm{O}_{4}$ spinels were used for $\mathrm{Mg}, \mathrm{Cr}$ and Fe determination, $\mathrm{Al}_{2} \mathrm{O}_{3}$ for $\mathrm{Al}, \mathrm{MnTiO}_{3}$ for Ti and $\mathrm{Mn}, \mathrm{NiO}$ for $\mathrm{Ni}$ and sphalerite for $\mathrm{Zn}$. The following diffracting crystals were used: TAP for Al and Mg, PET for $\mathrm{Ti}$ and $\mathrm{Ti}$, and LIF for $\mathrm{Cr}, \mathrm{Fe}, \mathrm{Mn}, \mathrm{Ni}, \mathrm{V}$ and $\mathrm{Zn}$. Raw data were reduced by a PAP-type correction software provided by CAMECA. The mineral chemical analyses are reported in Table 1.

\subsection{Cation Distribution}

According to [52,53], several different procedures may be adopted to determine cation distribution; satisfactory results can generally be obtained by combining data from singlecrystal X-ray structural refinements and electron microprobe analyses. In fact, this approach simultaneously takes into account both the structural and chemical data, reproducing the observed parameters by optimizing cation distributions. Differences between measured and calculated parameters are minimized by a function $\mathrm{F}(\mathrm{x})$, taking in consideration different observed quantities such as $\mathrm{a}_{0}, u, \mathrm{~T}$ - and $\mathrm{M}$ - m.a.n. (mean atomic number), atomic proportions, and constraints imposed by the crystal chemistry (total charges and $\mathrm{T}$ and $\mathrm{M}$ site populations). Several minimization cycles of $\mathrm{F}(\mathrm{x})$ were performed up to convergence. A summary of the procedure can be found in [54]. The obtained cation distributions are listed in a in Table 1.

\subsection{Mössbauer Spectroscopic Analysis}

Optical examination of the samples show minute amounts of opaque phases (magnetite) at the grain boundaries, which could be magnetically separated after crushing each to a fine powder under acetone.

Clean chromite crystals were selected under an optical microscope. About $50 \mathrm{mg}$ of each sample was used, distributed as $28 \mathrm{mg} / \mathrm{cm}^{2}$ of sample in the sample holder, as 
calculated via RECOIL 1.04 computer software [55,56]. Room temperature Mössbauer measurements were carried out on clean chromite separates with a $25 \mathrm{mCi}^{57} \mathrm{Co}$ source in a $\mathrm{Rh}$ matrix, which was driven at constant acceleration in a triangular mode. The Doppler energies from the $14.4 \mathrm{keV} \gamma$-rays were detected with a $\mathrm{YAlO}_{3}$ :Ce scintillation counter. Mössbauer measurements were repeated on replicas of all samples to check the consistency of our measurements.

Table 1. Results of structure refinement, chemistry and cation distribution. a: cell parameter $(\AA)$; u: oxygen positional parameter; R1: all (\%); wR2: (\%); GooF: as defined in [40]; $\mathrm{Cr} \#: \mathrm{Cr} /(\mathrm{Cr}+\mathrm{Al})$; $\mathrm{Mg} \#: \mathrm{Mg} /\left(\mathrm{Mg}+\mathrm{Fe}^{2+}\right) ; \mathrm{Fe}^{3+} \#: \mathrm{Fe}^{3+} /\left(\mathrm{Fe}^{3+}+\mathrm{Cr}+\mathrm{Al}\right) ; \mathrm{Tc}$ : intracrystalline closure temperature $\left({ }^{\circ} \mathrm{C}\right)$, calculated by using [26] geothermometer.

\begin{tabular}{|c|c|c|c|c|c|}
\hline & Sample & $5 B$ & $24 B$ & $30 \mathrm{~A}$ & $30 \mathrm{~B}$ \\
\hline \multirow[t]{5}{*}{ XRD } & a & $8.2364(4)$ & 8.2477 (3) & $8.2448(4)$ & $8.2399(4)$ \\
\hline & $u$ & $0.26355(5)$ & $0.26360(6)$ & $0.2633(1)$ & $0.2637(1)$ \\
\hline & R1 & 1.83 & 2.10 & 2.56 & 2.72 \\
\hline & wR2 & 3.92 & 4.12 & 6.08 & 6.33 \\
\hline & GooF & 1.186 & 1.311 & 1.244 & 1.198 \\
\hline \multirow[t]{15}{*}{ EMPA } & $\mathrm{MgO}$ & $8.2(1)$ & $6.80(9)$ & $9.2(3)$ & $6.8(1)$ \\
\hline & $\mathrm{Al}_{2} \mathrm{O}_{3}$ & $27.6(2)$ & $27.3(3)$ & $24.1(7)$ & $26.7(3)$ \\
\hline & $\mathrm{TiO}_{2}$ & $0.22(4)$ & $0.14(3)$ & $0.23(2)$ & $0.1483)$ \\
\hline & $\mathrm{Cr}_{2} \mathrm{O}_{3}$ & $35.8(4)$ & $36.0(5)$ & $38.5(8)$ & $36.4(3)$ \\
\hline & $\mathrm{MnO}$ & $0.23(3)$ & $0.26(3)$ & $0.23(3)$ & $0.26(3)$ \\
\hline & $\mathrm{FeO}_{\text {tot }}$ & $29.3(4)$ & $30.2(2)$ & $28.5(2)$ & $30.2(3)$ \\
\hline & $\mathrm{NiO}$ & $0.20(3)$ & $0.12(3)$ & $0.13(3)$ & $0.13(4)$ \\
\hline & Sum & 101.6 & 100.8 & 100.9 & 100.7 \\
\hline & T-site & & & & \\
\hline & $\mathrm{Mg}$ & 0.339 & 0.274 & 0.3644 & 0.2578 \\
\hline & $\mathrm{Al}$ & 0.0033 & 0.0298 & 0.0101 & 0.0353 \\
\hline & $\mathrm{Fe}^{2+}$ & 0.5622 & 0.6488 & 0.5357 & 0.6557 \\
\hline & $\mathrm{Fe}^{3+}$ & 0.0866 & 0.0362 & 0.0817 & 0.0393 \\
\hline & $\mathrm{Mn}$ & 0.006 & 0.0069 & 0.0061 & 0.0069 \\
\hline & $\mathrm{Zn}$ & 0.0025 & 0.0041 & 0.0016 & 0.0046 \\
\hline \multirow[t]{12}{*}{$\begin{array}{c}\text { Cation } \\
\text { distribution }\end{array}$} & M-site & & & & \\
\hline & $\mathrm{Al}$ & 1.0187 & 0.9804 & 0.9444 & 0.9715 \\
\hline & $\mathrm{Cr}$ & 0.8679 & 0.8854 & 0.9122 & 0.8958 \\
\hline & $\mathrm{Mg}$ & 0.0375 & 0.0425 & 0.0683 & 0.0609 \\
\hline & $\mathrm{Fe}^{2+}$ & 0.0454 & 0.0219 & 0.0208 & 0.0061 \\
\hline & $\mathrm{Fe}^{3+}$ & 0.0186 & 0.063 & 0.0443 & 0.057 \\
\hline & $\mathrm{Ni}$ & 0.0049 & 0.003 & 0.0032 & 0.0033 \\
\hline & $\mathrm{Ti}$ & 0.005 & 0.0033 & 0.0054 & 0.0033 \\
\hline & $\mathrm{Cr} \#$ & 0.46 & 0.48 & 0.49 & 0.47 \\
\hline & Mg\# & 0.38 & 0.32 & 0.44 & 0.33 \\
\hline & Fe\# & 0.05 & 0.05 & 0.06 & 0.05 \\
\hline & $\mathrm{Tc}$ & 715 & 924 & 754 & 966 \\
\hline
\end{tabular}

MossA (ver. 1.01a), a computer program developed by Prescher et al. [57], utilizing a full transmission integral with a normalized Lorentzian source line-shape, was used to fit the Lorentzian lines of the folded data. A fitting model consisting of three doublets assigned to $\mathrm{Fe}^{2+}$ and one doublet assigned to $\mathrm{Fe}^{3+}$, as used by Lenaz et al. [58], was adopted to fit the spectra. In addition, to obtain accurate quantification of $\mathrm{Fe}^{3+} / \Sigma \mathrm{Fe}$ for the chromite spectra, correction for the difference between the recoil-free fractions was applied to the chromite doublets for $\mathrm{Fe}^{2+}$ and $\mathrm{Fe}^{3+}$ at the tetrahedral and octahedral sites, respectively, at room temperature, based on previous studies [59-62], and calculated from the sample composition and the procedure enumerated. 
For accurate quantification of $\mathrm{Fe}^{3+} / \Sigma \mathrm{Fe}$ for the chromite spectra, we used the following unified equation, which incorporates the recoil free fractions, 0.687 and 0.887 , for the observed $\mathrm{Fe}^{2+}$ and $\mathrm{Fe}^{3+}$, respectively:

$$
\frac{\mathrm{Fe}^{3+}}{\Sigma \mathrm{Fe}}=\left[1-\frac{1}{(0.7745 x R+1)}\right]
$$

where $R$ is the $\left(\mathrm{Fe}^{3+} / \mathrm{Fe}^{2+}\right)$ ratio of the observed Fe-cations in the chromite doublets.

Mössbauer parameters obtained for centroid shift $\delta$, quadrupole splitting, $\Delta \mathrm{EQ}$ and the full width at half-maximum $\Gamma$, together with the averages of $\left(\mathrm{Fe}^{3+} / \sum \mathrm{Fe}\right)$ ratios for the samples and their respective replicas, are shown in Table 2. The identification of criteria for Fe-cation sites is based on the relative centroid shift $\delta$-values, following previous reports by $[62-64]$ : $\left[\delta-\mathrm{Fe}^{3+} \mathrm{T}\right]<\left[\delta-\mathrm{Fe}^{3+} \mathrm{M}\right]<\left[\delta-\mathrm{Fe}^{2+} \mathrm{T}\right]<\left[\delta-\mathrm{Fe}^{2+} \mathrm{M}\right]$. The site occupancy was determined from the area ratios of the doublets.

Table 2. Mössbauer parameters and corrected $\left(\mathrm{Fe}^{3+} / \Sigma \mathrm{Fe}\right)$ ratios obtained from (a) measurements of samples and (b) repeated measurements of three replica samples, respectively. $\delta=$ centroid shift $(\mathrm{mm} / \mathrm{s}), \Delta \mathrm{EQ}=$ quadrupole splitting $(\mathrm{mm} / \mathrm{s}), \Gamma=\mathrm{full}$ width at half-maximum $(\mathrm{mm} / \mathrm{s})$. The averages of $\left(\mathrm{Fe}^{3+} / \sum \mathrm{Fe}\right)$ ratios for the samples and their respective replicas are reported in this study.

\begin{tabular}{|c|c|c|c|c|c|c|c|c|c|c|}
\hline Samples & $\underset{(\mathrm{mm} / \mathrm{s})}{\delta}$ & $\begin{array}{c}\Delta \mathrm{E}_{\mathrm{Q}} \\
\mathrm{mm} / \mathrm{s}\end{array}$ & $\begin{array}{c}\Gamma \\
(\mathrm{mm} / \mathrm{s})\end{array}$ & $\begin{array}{c}\% \\
\text { Area }\end{array}$ & $\begin{array}{l}\text { Oxidation } \\
\text { State }\end{array}$ & $\begin{array}{c}x^{2} \\
( \pm \mathbf{0 . 1 2 6})\end{array}$ & $\left(\mathrm{Fe}^{2+} / \Sigma \mathrm{Fe}\right)$ & $\left(\mathrm{Fe}^{3+} / \Sigma \mathrm{Fe}\right)$ & $\left(\mathrm{Fe}^{3+} / \mathrm{Fe}^{2+}\right)$ & $\begin{array}{l}\left(\mathrm{Fe}^{3+} / \Sigma \mathrm{Fe}\right) \\
\text { Corrected }\end{array}$ \\
\hline $5 B$ & $\begin{array}{l}0.927 \\
0.920 \\
0.878 \\
0.347\end{array}$ & $\begin{array}{l}1.454 \\
0.883 \\
2.155 \\
0.657\end{array}$ & $\begin{array}{l}0.246 \\
0.221 \\
0.201 \\
0.142\end{array}$ & $\begin{array}{l}40.000 \\
21.200 \\
18.600 \\
20.490\end{array}$ & $\begin{array}{l}\mathrm{Fe}^{2+} \\
\mathrm{Fe}^{2+} \\
\mathrm{Fe}^{2+} \\
\mathrm{Fe}^{3+}\end{array}$ & 1.07 & 79.80 & 20.49 & 0.26 & 0.166 \\
\hline $24 B$ & $\begin{array}{l}0.934 \\
0.919 \\
0.901 \\
0.348\end{array}$ & $\begin{array}{l}1.479 \\
0.915 \\
2.133 \\
0.651\end{array}$ & $\begin{array}{l}0.446 \\
0.431 \\
0.401 \\
0.257\end{array}$ & $\begin{array}{l}36.412 \\
25.282 \\
21.989 \\
16.316\end{array}$ & $\begin{array}{l}\mathrm{Fe}^{2+} \\
\mathrm{Fe}^{2+} \\
\mathrm{Fe}^{2+} \\
\mathrm{Fe}^{3+}\end{array}$ & 1.04 & 83.68 & 16.32 & 0.20 & 0.131 \\
\hline $30 \mathrm{~A}$ & $\begin{array}{l}0.935 \\
0.926 \\
0.917 \\
0.364\end{array}$ & $\begin{array}{l}1.402 \\
2.042 \\
0.853 \\
0.616\end{array}$ & $\begin{array}{c}0.396 \\
0.38 \\
0.392 \\
0.256\end{array}$ & $\begin{array}{l}31.303 \\
25.614 \\
22.005 \\
21.078\end{array}$ & $\begin{array}{l}\mathrm{Fe}^{2+} \\
\mathrm{Fe}^{2+} \\
\mathrm{Fe}^{2+} \\
\mathrm{Fe}^{3+}\end{array}$ & 1.02 & 78.92 & 21.08 & 0.27 & 0.168 \\
\hline 30B & $\begin{array}{l}0.934 \\
0.930 \\
0.917 \\
0.345\end{array}$ & $\begin{array}{l}1.489 \\
0.910 \\
2.084 \\
0.660\end{array}$ & $\begin{array}{l}0.424 \\
0.413 \\
0.359 \\
0.225\end{array}$ & $\begin{array}{l}37.298 \\
30.121 \\
19.896 \\
12.684\end{array}$ & $\begin{array}{l}\mathrm{Fe}^{2+} \\
\mathrm{Fe}^{2+} \\
\mathrm{Fe}^{2+} \\
\mathrm{Fe}^{3+}\end{array}$ & 1.12 & 87.32 & 12.68 & 0.15 & 0.101 \\
\hline \multicolumn{11}{|l|}{$\begin{array}{l}\text { Samples } \\
\text { (b) }\end{array}$} \\
\hline $\begin{array}{c}\text { 5B } \\
\text { replica }\end{array}$ & $\begin{array}{l}0.934 \\
0.914 \\
0.878 \\
0.340\end{array}$ & $\begin{array}{l}1.521 \\
0.951 \\
2.188 \\
0.664\end{array}$ & $\begin{array}{l}0.427 \\
0.473 \\
0.381 \\
0.272\end{array}$ & $\begin{array}{l}31.032 \\
29.045 \\
18.808 \\
21.118\end{array}$ & $\begin{array}{l}\mathrm{Fe}^{2+} \\
\mathrm{Fe}^{2+} \\
\mathrm{Fe}^{2+} \\
\mathrm{Fe}^{3}\end{array}$ & 1.29 & 78.89 & 21.13 & 0.28 & 0.172 \\
\hline $\begin{array}{l}\text { 24B } \\
\text { replica }\end{array}$ & $\begin{array}{l}0.934 \\
0.922 \\
0.898 \\
0.353\end{array}$ & $\begin{array}{l}1.452 \\
0.905 \\
2.090 \\
0.653\end{array}$ & $\begin{array}{l}0.437 \\
0.425 \\
0.407 \\
0.241\end{array}$ & $\begin{array}{l}34.034 \\
25.467 \\
25.320 \\
15.180\end{array}$ & $\begin{array}{l}\mathrm{Fe}^{2+} \\
\mathrm{Fe}^{2+} \\
\mathrm{Fe}^{2+} \\
\mathrm{Fe}^{3+}\end{array}$ & 1.33 & 84.82 & 15.18 & 0.18 & 0.126 \\
\hline $\begin{array}{l}30 \mathrm{~A} \\
\text { replica }\end{array}$ & $\begin{array}{l}0.939 \\
0.936 \\
0.920 \\
0.359\end{array}$ & $\begin{array}{l}1.461 \\
2.075 \\
0.895 \\
0.621\end{array}$ & $\begin{array}{l}0.397 \\
0.369 \\
0.405 \\
0.262\end{array}$ & $\begin{array}{l}31.041 \\
23.495 \\
24.758 \\
20.707\end{array}$ & $\begin{array}{l}\mathrm{Fe}^{2+} \\
\mathrm{Fe}^{2+} \\
\mathrm{Fe}^{2+} \\
\mathrm{Fe}^{3+}\end{array}$ & 1.35 & 79.29 & 20.71 & 0.26 & 0.170 \\
\hline $\begin{array}{l}30 \mathrm{~B} \\
\text { replica }\end{array}$ & $\begin{array}{l}0.932 \\
0.920 \\
0.904 \\
0.360\end{array}$ & $\begin{array}{l}1.397 \\
0.852 \\
2.012 \\
0.634\end{array}$ & $\begin{array}{l}0.421 \\
0.391 \\
0.379 \\
0.219\end{array}$ & $\begin{array}{l}37.001 \\
25.873 \\
24.502 \\
12.624\end{array}$ & $\begin{array}{l}\mathrm{Fe}^{2+} \\
\mathrm{Fe}^{2+} \\
\mathrm{Fe}^{2+} \\
\mathrm{Fe}^{3+}\end{array}$ & 1.73 & 87.39 & 12.62 & 0.14 & 0.101 \\
\hline
\end{tabular}

\section{Results}

The composition of the analyzed grains of $\mathrm{Cr}$-spinel is quite similar to $\mathrm{Cr} \#$ in the range 0.46-0.49 and $\mathrm{Mg} \#$ in the range $0.32-0.44$, as calculated from analyses where $\mathrm{Cr}_{2} \mathrm{O}_{3}$ 
is in the range 35-39 wt.\%, $\mathrm{Al}_{2} \mathrm{O}_{3}$ 24-27 wt.\%, $\mathrm{MgO} 7-9$ wt.\% and $\mathrm{FeO}_{\text {tot }} 28-30$ wt.\% (Table 1). Other oxides that were detected are $\mathrm{MnO}, \mathrm{TiO}_{2}$ and $\mathrm{NiO}$, with concentrations below 0.30 wt.\%.

The structural parameters considered are the cell edges that range between 8.2364 (4) and 8.2477 (4) $\AA$ and the oxygen positional parameter, $u$, between 0.2633 (1) and 0.2637 (1). This last parameter is related to the oxygen packing distortion within the lattice. The ideal cubic-close packed structure shows $u=0.25$, but it is observed that $u$ is higher than 0.25 for all four samples of $\mathrm{Cr}$-bearing spinels. The observed distortion is a consequence of similar M-O and T-O bond distances $(u=0.2625$ when distances are equal) [65]. Previous studies suggested that 0.2625 and, consequently, the T-O and $\mathrm{M}-\mathrm{O}$ bond distances are related to the cooling history experienced by the mineral. Slow cooling allows the cations to accommodate at their preferred site, i.e., trivalent cations at the octahedral $\mathrm{M}$ site and divalent cations at the tetrahedral $\mathrm{T}$ site. On the contrary, rapid cooling causes a disordered cation distribution between the two sites, with trivalent and divalent cations in both $\mathrm{T}$ and M sites. As can be seen in Tables 1 and 2, the values found for these Cr-spinels are among the highest recorded $u$ values, thereby pointing to very slow cooling rates. The degree of inversion, $i$, i.e., the amounts of trivalent cations at $\mathrm{T}$ site or divalent cations at $\mathrm{M}$ site, is in the range of $0.066-0.092$ atoms per formula unit.

Figure 3 shows spectra of samples 5B and 30B_rep, as typical examples of Mössbauer spectra, for a four-doublet fitting model, which provided a good $\chi^{2}$-value for the fitting of the Sittampundi chromite spectra. As the spectra show limited resolution, which is typical for this type of chromite, the assignment of individual doublets to specific sites is uncertain. However, the $\mathrm{Fe}^{3+} / \Sigma \mathrm{Fe}$ ratios obtained are considerably more reliable, as the $\mathrm{Fe}^{3+}$ absorption is well constrained by the asymmetry of the two main high- and lowvelocity components in the measured spectra, where the $\mathrm{Fe}^{3+}$ contribution occurs entirely within the low-velocity component.
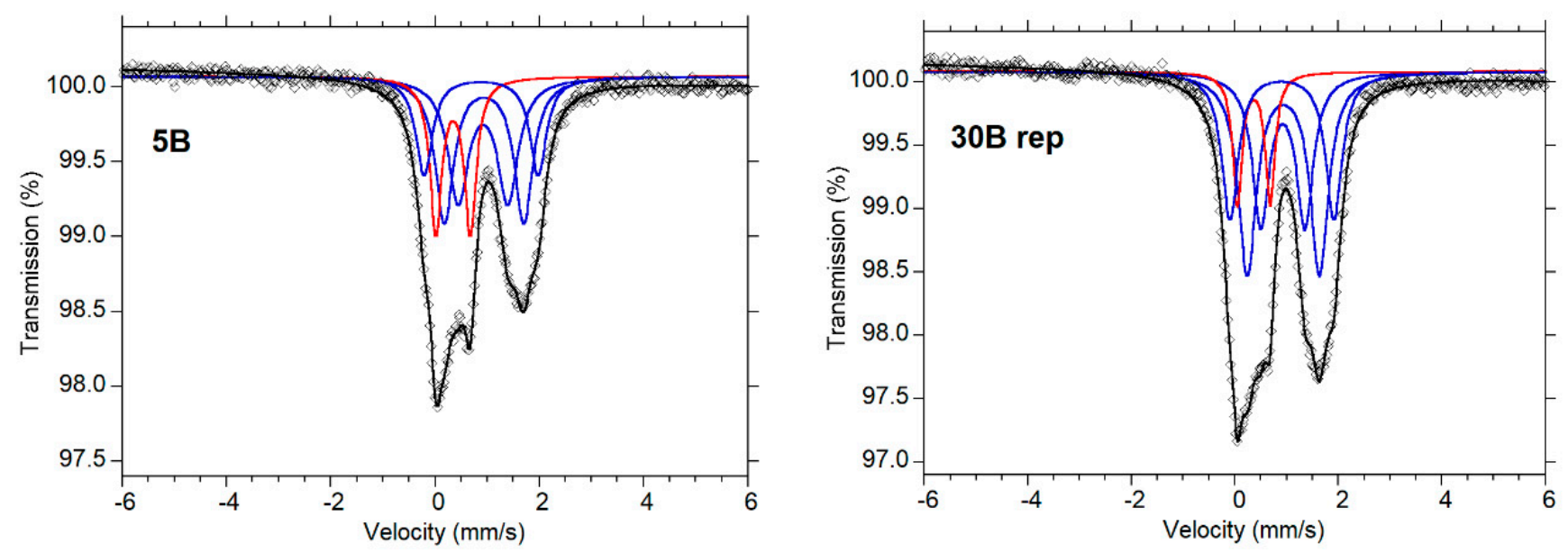

Figure 3. Examples of ${ }^{57} \mathrm{Fe}$ Mössbauer spectra obtained at room temperature for samples 5B and 30B rep. Fitted absorption doublets assigned to $\mathrm{Fe}^{2+}$ and $\mathrm{Fe}^{3+}$ are indicated in blue and red colors, respectively. Diamond symbols denote measured spectra, and the black curves represent summed fitted spectra.

Table 2 shows the room temperature Mössbauer data for (a) all samples and (b) the repeated runs on replicas. The calculated average of their respective corrected $\left(\mathrm{Fe}^{3+} / \mathrm{Fe}\right)$ ratios in the Tables are, $0.13,0.17$ and 0.10 , respectively.

According to microprobe analyses, structural refinement and Mössbauer analyses data, the values of $\left(\mathrm{Fe}^{3+} / \Sigma \mathrm{Fe}\right)$ ratios in the Sittampundi chromite-spinels are in the range $10-18 \%$. However, on the basis of the values of the quadrupole splittings of the $\mathrm{Fe}^{3+}$ doublets, it appears all $\mathrm{Fe}^{3+}$ ions preferentially occupy the T-site. 


\section{Discussion}

In terms of mineralogy and field relations, the Sittampundi chromitites are remarkably similar to anorthosite-hosted chromitites in the Neoarchean Fiskenæsset anorthositic complex, Greenland. In Figure 4, we compare the structural parameters of the studied Cr-spinels with those of other occurrences that are similar in age. In fact, there are some other Archean occurrences, such as the Fiskenæsset and Ujragassuit (Greenland) [35], Amsaga (Mauritania) [34], Inyala and Rhonda (Limpopo belt, Zimbabwe) [35], detrital Cr-spinels from Banavara [66], as well as the Bushveld and Stillwater Complexes [31,33]. Moreover, the figure comprises the $\mathrm{Cr}$-spinels in seams entrapped within anorthosites from the Paleogene Rum Layered Complex [32].

In Amsaga, the chromites can be found associated with different matrix minerals, according to the metamorphic grade that affected the rocks. Those with the higher $u$ values are metamorphosed in amphibolite facies and are very close to the parameters exhibited by Sittampundi Cr-spinels. Fiskenæsset chromitites, even if their paragenesis also includes pargasitic amphiboles, as in Sittampundi, have to be considered as primary and not metamorphosed $[67,68]$. In order to estimate the intracrystalline closure temperatures of the Cr-spinels, we applied to our samples the geothermometer of [26]. This geothermometer takes into account the $\mathrm{Mg}$ and $\mathrm{Al}$ content of the $\mathrm{Cr}$-spinels and their distribution amongst the octahedral and tetrahedral sites. The presence of other cations is accounted for by coefficients present in the equation of the geothermometer. The calculated intracrystalline closure temperature $(T c)$ for the Sittampundi $\mathrm{Cr}$-spinels is in the range of $715-965^{\circ} \mathrm{C}$. The computed intracrystalline closure temperature is more or less in agreement with the temperature obtained by topological constraints and quantitative geothermometry of the area $[39,41]$. In Figure 5, we compare these temperatures with those of Rum, Fiskenæsset and Amsaga complexes. It is possible to see that those from Rum are the lowest $\left(521-653^{\circ} \mathrm{C}\right)$, while the others are more or less comparable.

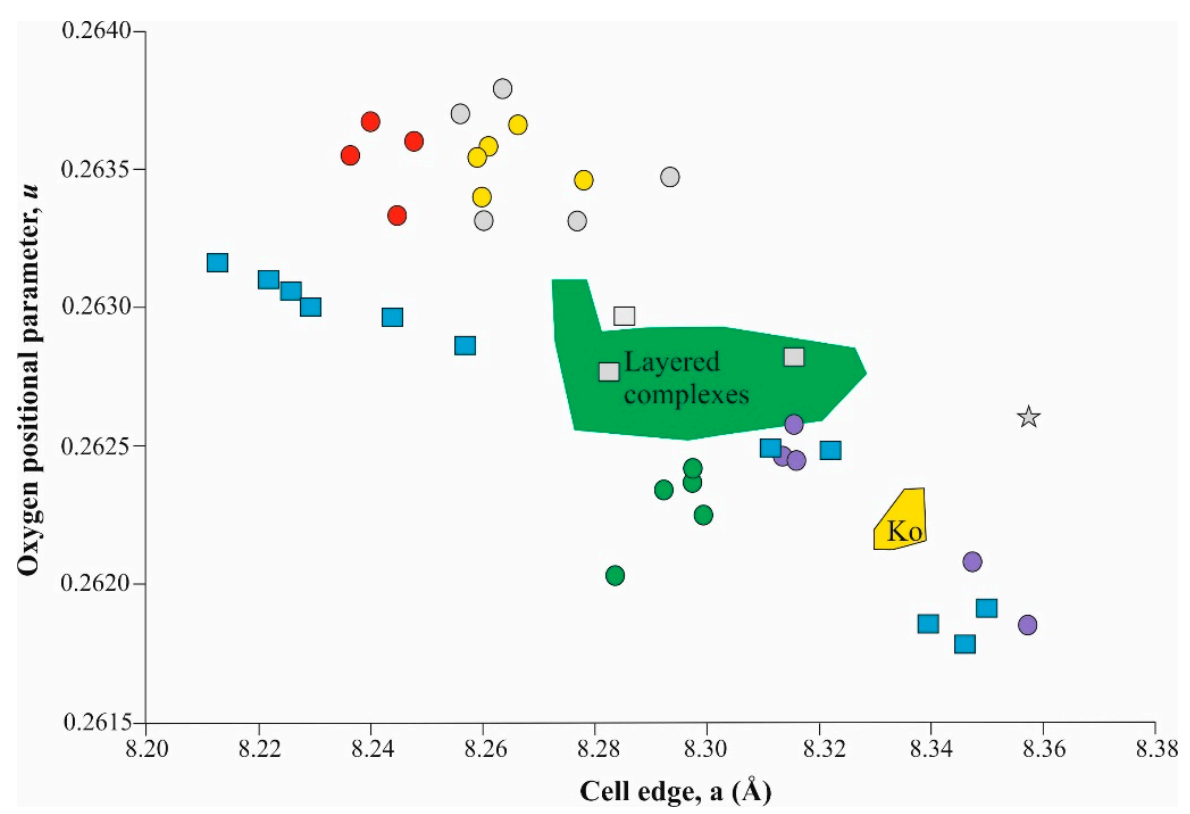

Figure 4. Oxygen positional parameter, $u$, versus cell edge, a. Black circles: Cr-spinels from Sittampundi (this study); red circles: detrital Cr-spinels from Banavara [66]; grey circles, squares and star: Cr-spinels from Amsaga (Mauritania) in amphibole, chlorite and talc-serpentine matrix, respectively [34]; yellow, purple and green circles: Cr-spinels from Fiskenaesset and Ujragassuit (Greenland) and Zimbabwe, respectively [35]; blue squares: Cr-spinels from Rum (Scotland) [32]; green field: Cr-spinels from Bushveld and Stillwater complexes [31,33]; yellow field: Cr-spinels from Nuggihalli komatiites [69]. 
Rum

Amsaga

Fiskenaesset

Sittampundi

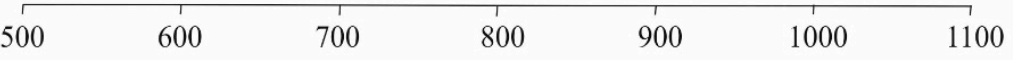

Intracrystalline closure temperature, ${ }^{\circ} \mathrm{C}$

Figure 5. Range of intracrystalline closure temperatures $\left({ }^{\circ} \mathrm{C}\right)$ for the spinel composition investigated and other occurrences of $\mathrm{Cr}$-spinels from chromitites in anorthosites used for comparison (Fiskenæsset, unpublished data; Amsaga [34]; Rum [32]).

It is interesting to note that Amsaga Cr-spinels record an intracrystalline closure temperature higher than that of the amphibolite facies; thus, it is possible they still retain the primary closure temperature after crystallization. Sittampundi Cr-spinels underwent a granulite facies metamorphism. Sunder Raju [70] noticed that the pristine composition of the chromites is preserved despite intense metamorphic and tectonic processes. In this case, the highest temperatures are comparable with those of the metamorphism, but they extend down to about $700{ }^{\circ} \mathrm{C}$. It is pertinent to remember that the intracrystalline closure temperature is the temperature recording the last $\mathrm{Mg}-\mathrm{Al}$ exchange between $\mathrm{T}$ and $\mathrm{M}$ sites and not the temperature of crystallization. Thus, they suffered a high temperature metamorphism and then slowly cooled until their actual Tc was achieved.

In the past few years, some papers have dealt with the possibility of non-stoichiometry in Cr-spinels from different occurrences. This was determined using a combination of techniques, including structural refinement, electron microprobe and Mössbauer analysis. The authors [18,71,72] found some Cr-spinels from ophiolites to be non-stoichiometric, i.e., showing structural vacancies in the lattice due to the oxidation of $\mathrm{Fe}^{2+}$ to $\mathrm{Fe}^{3+}$. Furthermore, some authors $[73,74]$ also documented the existence of minor vacancies in Cr-spinels from the Bushveld layered complex and some Antarctica mantle xenoliths, respectively. However, when the same combined approach was used for other ophiolites (Shetland, UK, [75]; Leka, Norway, [76]) and the Amsaga complex in Mauritania ([34], no vacancies were detected. Using both the conventional- and point- ${ }^{57} \mathrm{Co}$-source methods, [58] showed how, in some cases, there can be large discrepancies in the $\left(\mathrm{Fe}^{3+} / \Sigma \mathrm{Fe}\right)$ ratios calculated via structural refinement, electron microprobe and Mössbauer analyses. The reason, for example, is that the larger samples used in conventional Mössbauer techniques include several different grains, which could have a range of very different degrees of oxidation. Here, we can see that the values of $\mathrm{Fe}^{3+} / \Sigma \mathrm{Fe}$ obtained for the Sittampundi Cr-spinels using various experimental techniques are very similar, thus allowing us to conclude that these samples of spinel are stoichiometric.

Although chemical modifications related to sub-solidus re-equilibration and metamorphic hydrothermal processes can significantly influence the primary high-T composition of Cr-spinel, the composition of chromite in chromitite bodies can still be used as a petrogenetic and geotectonic indicator [77]. Suita and Streider [78] showed that the core of Cr-spinel grains in massive chromitites conserves the primary chemical composition, regardless of the metamorphic changes. Notably, the degree of metamorphic re-equilibration in metamorphosed chrome-spinels depends on the ratio of $\mathrm{P}_{\mathrm{H}_{2} \mathrm{O}}$ and $\mathrm{P}_{\text {total }}$. According to [79], when $\mathrm{P}_{\mathrm{H}_{2} \mathrm{O}}$ is about $25 \%$ of $\mathrm{P}_{\text {total }}$, a complete metamorphic re-equilibration occurs; 
however, where it is lower, relict igneous cumulate textures are preserved. In fact, ref. [80] suggested that in high pressure conditions, there is no resetting of the primary igneous composition of chromites. The composition of mantle fluid phases attending magmatic and metasomatic processes strongly depends on oxygen fugacity $\left(f \mathrm{O}_{2}\right)$. So, in the C-H-O system, the fluid phase consists mainly of $\mathrm{CO}_{2}$ and $\mathrm{H}_{2} \mathrm{O}$ in relatively oxidizing conditions close to the fayalite-magnetite-quartz (FMQ) solid buffer, $\mathrm{H}_{2} \mathrm{O}$ and $\mathrm{CH}_{4}$ in moderately oxidizing conditions between the FMQ and iron-wüstite (IW) buffers, and $\mathrm{CH}_{4}$ below IW [81]. For Albanian ophiolites, [82] found that the pre-oxidation $\Delta \log \left(f_{2}\right) \mathrm{FMQ}$ values range from -3.2 to +2.3 log units, with most values close to or higher than the FMQ buffer, while the post-oxidation $\triangle \log \left(f \mathrm{O}_{2}\right) \mathrm{FMQ}$ values are systematically the highest, ranging from +0.5 to $+2.9 \log$ units. A report by [62] showed that there are two groups of spinels in ophiolites from Oman, with different oxygen fugacities. The calculated oxygen fugacities for the low $\mathrm{Fe}^{3+} / \Sigma \mathrm{Fe}$ ratio group are between 1.9 and $2.7 \log$ units above the FMQ buffer, while samples from the high $\mathrm{Fe}^{3+} / \Sigma \mathrm{Fe}$ ratio group yield higher oxygen fugacities, between 3.2 and $3.4 \log$ units above the FMQ buffer. It is therefore most likely that the $\mathrm{P}_{\mathrm{H}_{2} \mathrm{O}}$ and $\mathrm{P}_{\text {total }}$ values, as well as both the oxygen fugacity and the temperature reached during different processes, inhibits the possibility of non-stoichiometry of chromites from amphibolite-granulite-eclogite facies, as in Amsaga and Sittampundi, contrary to what can happen in ophiolites.

\section{Conclusions}

According to the combined results from structural refinement, electron microprobe and Mössbauer analyses of the Sittampundi Cr-spinels, the following can be concluded:

(i) Oxygen parameters of the studied $\mathrm{Cr}$-spinels are close to the Amsaga chromites.

(ii) The computed intracrystalline closure temperature of the Cr-spinels is comparable to the reported temperatures obtained by topological constraints and quantitative geothermometry.

(iii) Estimated values of $\mathrm{Fe}^{3+} / \Sigma \mathrm{Fe}$ ratios obtained by using different techniques are similar and establish that the studied Sittampundi Cr-spinels are stoichiometric.

(iv) Structural refinement study of $\mathrm{Cr}$-spinels could be important in discriminating the various tectonic domains.

Author Contributions: Conceptualization, D.L. and B.M.; methodology, D.L., B.M., J.A. and H.S.; formal analysis, D.L., B.M., J.A. and H.S.; writing-original draft preparation, D.L., B.M., J.A. and H.S.; writing-review and editing, D.L. and B.M. All authors have read and agreed to the published version of the manuscript.

Funding: This research received no external funding.

Data Availability Statement: Not applicable.

Acknowledgments: The Italian C.N.R. financed the installation and maintenance of the microprobe laboratory in Padua. R. Carampin and L. Tauro are kindly acknowledged for technical support. H.S. acknowledges support from the Swedish Research Council. J.A would like to thank the College of Science and Engineering, University of Derby, for their support in his Mössbauer spectroscopy research. B.M. would like to thank S. Mitra for the encouragement to carry out this research work.

Conflicts of Interest: The authors declare no conflict of interest.

\section{References}

1. Rao, Y.B.; Chetty, T.R.K.; Janardhan, A.S.; Gopalan, K. Sm-Nd and Rb-Sr ages and PT history of the Archean Sittampundi and Bhavani layered meta-anorthosite complexes in Cauvery shear zone, South India: Evidence for Neoproterozoic reworking of Archean crust. Contrib. Mineral. Petrol. 1996, 125, 237-250. [CrossRef]

2. Subramaniam, A.P. Mineralogy and petrology of the Sittampundi Complex, Salem district, Madras state, India. Geol. Soc. Am. Bull. 1956, 67, 317-390. [CrossRef]

3. Janardhanan, A.S.; Leake, B.E. The origin of the meta-anorthositic gabbros and garnetiferous granulites of the Sittampundi complex, Madras, India. J. Geol. Soc. India 1975, 16, 391-408.

4. Windley, B.F.; Selvan, T.A. Anorthosites and associated rocks of Tamil Nadu, southern India. J. Geol. Soc. India 1975, 16, $209-215$. 
5. Windley, B.F.; Bishop, F.C.; Smith, J.V. Metamorphosed layered igneous complexes in Archean granulite-gneiss belts. Ann. Rev. Earth Planet. Sci. 1981, 9, 175-198. [CrossRef]

6. Sajeev, K.; Windley, B.F.; Connolly, J.A.D.; Kon, Y. Retrogressed eclogite $\left(20 \mathrm{kbar}, 1020^{\circ} \mathrm{C}\right)$ from the Neoproterozoic PalghatCauvery suture zone, southern India. Precambrian Res. 2009, 171, 23-36. [CrossRef]

7. Ghosh, B.; Konar, R. Chromites from meta-anorthosites, Sittampundi layered igneous complex, Tamil Nadu, southern India. J. Asian Earth Sci. 2011, 42, 1394-1402. [CrossRef]

8. Ahmed, A.H.; Arai, S.; Abdel-Aziz, Y.M.; Rahimi, A. Spinel composition as a petrogenetic indicator of the mantle section in the Neoproterozoic Bou Azzer ophiolite, Anti-Atlas, Morocco. Precambrian Res. 2005, 138, 225-234. [CrossRef]

9. González Jiménez, J.M.; Kerestedjian, T.; Proenza, F.J.A.; Gervilla, F. Metamorphism on chromite ores from the Dobromirtsi ultramafic massif, Rhodope Mountains (SE Bulgaria). Geol. Acta 2009, 7, 413-429.

10. Colas, V.; González-Jiménez, J.M.; Griffin, W.L.; Fanlo, I.; Gervilla, F.; O’Reilly, S.Y.; Pearson, N.J.; Kerestedjian, T.; Proenza, J.A. Fingerprints of metamorphism in chromite: New insights from minor and trace elements. Chem. Geol. 2014, 389, 137-152. [CrossRef]

11. Evans, B.W.; Frost, B.R. Chrome-spinel in progressive metamorphism-A preliminary analysis. Geochim. Cosmochim. Acta 1975, 39, 959-972. [CrossRef]

12. Kimball, K.L. Effects of hydrothermal alteration on the composition of chromian spinels. Contrib. Mineral. Petrol. 1990, 105, 337-346. [CrossRef]

13. Burkhard, D.J.M. Accessory chromium spinels: Their coexistence and alteration in serpentinites. Geochim. Cosmochim. Acta 1993, 57, 1297-1306. [CrossRef]

14. Barnes, S.J. Chromite in komatiites, II. Modification during greenschist to mid amphibolite facies metamorphism. J. Petrol. 2000, 41, 387. [CrossRef]

15. Della Giusta, A.; Princivalle, F.; Carbonin, S. Crystal chemistry of a suite of natural Cr-bearing spinels with $0.15<\mathrm{Cr}<1.07$. Neues Jahrb. Mineralogie. Abh. 1986, 155, 319-330.

16. Princivalle, F.; Della Giusta, A.; Carbonin, S. Comparative crystal chemistry of spinels from some suits of ultramafic rocks. Mineral. Petrol. 1989, 40,117-126. [CrossRef]

17. Carraro, A. Crystal chemistry of Cr-spinels from a suite of spinel peridotite mantle xenoliths from the Predazzo Area (Dolomites, Northern Italy). Eur. J. Mineral. 2003, 15, 681-688. [CrossRef]

18. Bosi, F.; Andreozzi, G.B.; Ferrini, V.; Lucchesi, S. Behavior of cation vacancy in kenotetrahedral Cr-spinels from Albanian eastern belt ophiolites. Am. Mineral. 2004, 89, 1367-1373. [CrossRef]

19. Uchida, H.; Lavina, B.; Downs, R.T.; Chesley, J. Single-crystal X-ray diffraction of spinels from the San Carlos Volcanic Field, Arizona: Spinel as a geothermometer. Am. Mineral. 2005, 90, 1900-1908. [CrossRef]

20. Lenaz, D.; Logvinova, A.M.; Princivalle, F.; Sobolev, N.V. Structural parameters of chromite included in diamond and kimberlites from Siberia: A new tool for discriminating ultramafic source. Am. Mineral. 2009, 94, 1067-1070. [CrossRef]

21. Lenaz, D.; De Min, A.; Garuti, G.; Zaccarini, F.; Princivalle, F. Crystal chemistry of Cr-spinels from the lherzolite mantle peridotite of Ronda (Spain). Am. Mineral. 2010, 95, 1323-1328. [CrossRef]

22. Lenaz, D.; Youbi, N.; De Min, A.; Boumehdi, M.A.; Ben Abbou, M. Low intra-crystalline closure temperatures of Cr-bearing spinels from the mantle xenoliths of the Middle Atlas Neogene-Quaternary Volcanic Field (Morocco): A mineralogical evidence of a cooler mantle beneath the West African Craton. Am. Mineral. 2014, 99, 267-275. [CrossRef]

23. Lenaz, D.; Musco, M.E.; Petrelli, M.; Caldeira, R.; De Min, A.; Marzoli, A.; Mata, J.; Perugini, D.; Princivalle, F.; Boumehdi, M.A.; et al. Restitic or not? Insights from trace element content and crystal—Structure of spinels in African mantle xenoliths. Lithos 2017, 278-281, 464-476. [CrossRef]

24. Lavina, B.; Cesare, B.; Álvarez-Valero, A.M.; Uchida, H.; Downs, R.T.; Koneva, A.; Dera, P. Closure temperatures of intracrystalline ordering in anatectic and metamorphic hercynite, $\mathrm{Fe}^{2+} \mathrm{Al}_{2} \mathrm{O}_{4}$. Am. Mineral. 2009, 94, 657-665. [CrossRef]

25. Ganguly, J. Mg-Fe order-disorder in ferromagnesian silicates. II Thermodynamics, kinetics and geological applications. In Advances in Physical Geochemistry; Saxena, S.K., Ed.; Springer: New York, NY, USA, 1982; Volume 2, pp. 58-59.

26. Princivalle, F.; Della Giusta, A.; De Min, A.; Piccirillo, E.M. Crystal chemistry and significance of cation ordering in Mg-Al rich spinels from high-grade hornfels (Predazzo-Monzoni, NE Italy). Mineral. Mag. 1999, 63, 257-262. [CrossRef]

27. Bosi, F; Andreozzi, G.B. Chromium influence on $\mathrm{Mg}$-Al intracrystalline exchange in spinels and geothermometric implications. Am. Mineral. 2017, 102, 333-340. [CrossRef]

28. Mattioli, G.S.; Wood, B.J. Magnetite activities across the $\mathrm{MgAl}_{2} \mathrm{O}_{4}-\mathrm{Fe}_{3} \mathrm{O}_{4}$ spinel join, with application to thermobarometric estimates of upper mantle oxygen fugacity. Contrib. Mineral. Petrol. 1988, 98, 148-162. [CrossRef]

29. Ballhaus, C.; Berry, R.F.; Green, D.H. High pressure experimental calibration of the olivine-orthopyroxene-spinel oxygen geobarometer: Implications for the oxidation state of the upper mantle. Contrib. Mineral. Petrol. 1991, 107, 27-40. [CrossRef]

30. Ozawa, K. Evaluation of olivine-spinel geothermometry as an indicator of thermal history for peridotites. Contrib. Mineral. Petrol. 1983, 82, 52-65. [CrossRef]

31. Lenaz, D.; Braidotti, R.; Princivalle, F.; Garuti, G.; Zaccarini, F. Crystal chemistry and structural refinement of chromites from different chromitite layers and xenoliths of the Bushveld Complex. Eur. J. Mineral. 2007, 19, 599-609. [CrossRef]

32. Lenaz, D.; O'Driscoll, B.; Princivalle, F. Petrogenesis of the anorthosite-Chromitite association: Crystal-chemical and petrological insights from the Rum Layered Intrusion, NW Scotland. Contrib. Mineral. Petrol. 2011, 162, 1201-1213. [CrossRef] 
33. Lenaz, D.; Garuti, G.; Zaccarini, F.; Cooper, R.W.; Princivalle, F. The Stillwater Complex: The response of chromite crystal chemistry to magma injection. Geol. Acta 2012, 10, 33-41.

34. Lenaz, D.; Rigonat, N.; Skogby, H.; Berger, J. Following the amphibolite to greenschist metamorphic path through the structural parameters of spinels from Amsaga (Mauritania). Minerals 2018, 8, 27. [CrossRef]

35. Rollinson, H.; Adetunji, J.; Lenaz, D.; Szilas, K. Archaean chromitites show constant $\mathrm{Fe}^{3+} / \Sigma \mathrm{Fe}$ in Earth's asthenospheric mantle since 3.8 Ga. Lithos 2017, 282-283, 316-325. [CrossRef]

36. Dharma Rao, C.V.; Santosh, M.; Sajeev, K.; Windley, B.F. Chromite-silicate chemistry of the Neoarchean Sittampundi Complex, southern India: Implications for subduction-related arc magmatism. Precambrian Res. 2013, 227, 259-275. [CrossRef]

37. Chowdhury, P.; Talukdar, M.; Sengupta, P.; Sanyal, S.; Mukhopadhyay, D. Controls of P-T path and element mobility on the formation of corundum pseudomorphs in Paleoproterozoic high-pressure anorthosite from Sittampundi, Tamil Nadu, India. Am. Mineral. 2013, 98, 1725-1737. [CrossRef]

38. Mohan, M.R.; Satyanarayanan, M.; Santosh, M. Neoarchean suprasubduction zone arc magmatism in southern India: Geochemistry, zircon $\mathrm{U}-\mathrm{Pb}$ geochronology and Hf isotopes of the Sittampundi Anorthosite Complex. Gondwana Res. 2013, 23, 539-557. [CrossRef]

39. Talukdar, M.; Sanyal, S.; Sengupta, P. Metasomatic alteration of chromite from parts of the late Archaean Sittampundi Layered Magmatic Complex (SLC), Tamil Nadu, India. Ore Geol. Rev. 2017, 90, 148-165. [CrossRef]

40. Dutta, U.; Bhui, U.K.; Sengupta, P.; Sanyal, S.; Mukhopadhyay, D. Magmatic and metamorphic imprints in 2.9 Ga chromitites from the Sittampundi layered complex, Tamil Nadu, India. Ore Geol. Rev. 2011, 40, 90-107. [CrossRef]

41. Karmakar, S.; Mukherjee, S.; Sanyal, S.; Sengupta, P. Origin of peraluminous minerals (corundum, spinel, and sapphirine) in a highly calcic anorthosite from the Sittampundi Layered Complex, Tamil Nadu, India. Contrib. Mineral. Petrol. 2017, 172, 67. [CrossRef]

42. Mitra, S.; Bidyananda, M.; Samanta, A.K. Cation distribution in Cr-spinels from the Sittampundi layered complex and their intracrystalline thermodynamics. Curr. Sci. 2006, 90, 435-439.

43. Carbonin, S.; Menegazzo, G.; Lenaz, D.; Princivalle, F. Crystal chemistry of two detrital Cr -spinels with unusually low values of oxygen positional parameter: Oxidation mechanism and possible origin. Neues Jahrb. Mineral. Mon. 1999, 359-371.

44. Thesniya, P.M.; Saranya, R.; Rajesh, V.J. Compositional and spectrochemical analyses of Cr-spinels in the Sittampundi Anorthosite Complex, Southern India: Implications for remote observations of spinels on the Moon. Spectrochim. Acta Part A Mol. Biomol. Spectrosc. 2021, 255, 119677. [CrossRef]

45. D'Ippolito, V.; Andreozzi, G.B.; Bersani, D.; Lottici, P.P. Raman fingerprint of chromate, aluminate and ferrite spinels. J. Raman Spectrosc. 2015, 46, 1255-1264. [CrossRef]

46. Lenaz, D.; Lughi, V. Raman study of $\mathrm{MgCr}_{2} \mathrm{O}_{4}-\mathrm{Fe}^{2+} \mathrm{Cr}_{2} \mathrm{O}_{4}$ and $\mathrm{MgCr}_{2} \mathrm{O}_{4}-\mathrm{MgFe}^{3+}{ }_{2} \mathrm{O}_{4}$ synthetic series: The effects of Fe ${ }^{2+}$ and $\mathrm{Fe}^{3+}$ on Raman shifts. Phys. Chem. Miner. 2013, 40, 491-498. [CrossRef]

47. Lenaz, D.; Lughi, V. Raman spectroscopy and the inversion degree of natural Cr-bearing spinels. Am. Mineral. 2017, 102, 327-332. [CrossRef]

48. Della Giusta, A.; Carbonin, S.; Ottonello, G. Temperature-dependent disorder in a natural Mg—Al—Fe $\mathrm{Fe}^{2+}-\mathrm{Fe}^{3+}-\mathrm{spinel}$. Mineral. Mag. 1996, 60, 603-616. [CrossRef]

49. Sheldrick, G.M. A short history of SHELX. Acta Crystallogr. Sect. A Found. Crystallogr. 2008, 64, 112-122. [CrossRef]

50. Prince, E. International Tables for X-ray Crystallography. Volume C: Mathematical, Physical and Chemical Tables, 3rd ed.; Springer: Dordrecht, The Netherlands, 2004.

51. Tokonami, M. Atomic scattering factor for O-2. Acta Crystallogr. 1965, 19, 486. [CrossRef]

52. Carbonin, S.; Russo, U.; Della Giusta, A. Cation distribution in some natural spinels from X-ray diffraction and Mössbauer spectroscopy. Mineral. Mag. 1996, 60, 355-368. [CrossRef]

53. Lavina, B.; Salviulo, G.; Della Giusta, A. Cation distribution and structure modeling of spinel solid solutions. Phys. Chem. Miner. 2002, 29, 10-18. [CrossRef]

54. Lenaz, D.; Schmitz, B. Crystal structure refinement of chromites from two achondrites, their T- $f\left(\mathrm{O}_{2}\right)$ conditions and implications. Meteor. Planet. Sci. 2017, 52, 1763-1775. [CrossRef]

55. Lagarec, K.; Rancourt, G.K. Extended Voigt-based analytic line-shape method for determining N -dimensional correlated hyperfine parameter distributions in Mossbauer Spectroscopy. Nucl. Instrum. Methods Phys. Res. Sect. B Beam Interact. Mater. At. 1997, 129, 266-280. [CrossRef]

56. Lagarec, K.; Rancourt, G.K. Recoil Spectral Analysis Software for Windows; Version 1.0; Mössbauer Group, Physics Department, University of Ottawa: Ottawa, ON, Canada, 1998.

57. Prescher, C.; McCammon, C.; Dubrovinsky, L. MossA 1.01: A program for analyzing energy-domain Mössbauer spectra from Conventional and Synchrotron sources. J. Appl. Crystallogr. 2012, 45, 329-331. [CrossRef]

58. Lenaz, D.; Skogby, H.; Logvinova, A.M.; Sobolev, N.V.; Princivalle, F. A micro-Mössbauer study of chromites included in diamond and other mantle related rocks. Phys. Chem. Miner. 2013, 40, 671-679. [CrossRef]

59. De Grave, E.; Van Alboom, A. Evaluation of ferrous and ferric Mössbauer fractions. Phys. Chem. Miner. 1991, 18, 337-342. [CrossRef]

60. Eeckhout, S.G.; De Grave, E. Evaluation of ferrous and ferric Mössbauer fractions. Part II. Phys. Chem. Miner. 2003, 30, 142-146. [CrossRef] 
61. Quintiliani, M. ${ }^{57} \mathrm{Fe}$ Mössbauer spectroscopy analysis of spinels: $\mathrm{Fe}^{3+} / \Sigma \mathrm{Fe}$ quantification accuracy and consequences on $f \mathrm{O}_{2}$ estimate. Period. Mineral. 2005, 74, 139-146.

62. Rollinson, H.; Adetunji, J.; Yousif, A.A.; Gismelseed, A.M. New Mössbauer measurements of Fe ${ }^{3+} / \Sigma F e$ in chromites from the mantle section of the Oman ophiolite: Evidence for the oxidation of the sub-oceanic mantle. Mineral. Mag. 2012, 76, 579-596. [CrossRef]

63. Pal, T.; Moon, H.; Mitra, S. Distribution of iron cations in natural chromites at different stages of oxidation-A ${ }^{57} \mathrm{Fe}$ Mössbauer investigation. J. Geol. Soc. India 1994, 44, 53-64.

64. Rais, A.; Yousif, A.A.; Al-Shishi, M.H.; Al-Rawas, A.D.; Gismelseed, A.M.; El-Zain, M.E. Cation distribution and magnetic properties of natural chromites. Phys. Status Solidi (b) 2003, 739, 439-444. [CrossRef]

65. Hill, R.J.; Craig, J.R.; Gibbs, G.V. Systematics of the spinel structure type. Phys. Chem. Miner. 1979, 4, 317-339. [CrossRef]

66. Maibam, B.; Lenaz, D.; Foley, S.; Berndt, J.; Belousova, E.; Wangjam, M.; Goswami, J.N.; Kapsiotis, A. U-Pb and Hf isotope study of detrital zircon and Cr-spinel in Banavara quartzite and implications for the evolution of the Dharwar crato, South India. Geol. Mag. 2021, 158, 1671-1682. [CrossRef]

67. Rollinson, H.R.; Reid, C.; Windley, B.F. Chromitites from the Fiskenæsset anorthositic complex, West Greenland: Clues to late Archaean mantle processes. Geol. Soc. Lond. Spec. Publ. 2010, 338, 197-212. [CrossRef]

68. Polat, A.; Fryer, B.J.; Appel, P.W.U.; Kalvig, P.; Kerrich, R.; Dilek, Y.; Yang, Z. Geochemistry of anorthositic differentiated sills in the Archean ( 2970 Ma) Fiskenaesset Complex, SW Greenland: Implications for parental magma compositions, geodynamic setting, and secular heat flow in arcs. Lithos 2011, 123, 50-72. [CrossRef]

69. Lenaz, D.; Andreozzi, G.B.; Mitra, S.; Maibam, B.; Princivalle, F. Crystal chemical and 57Fe Mössbauer study of chromite from the Nuggihalli schist belt (India). Mineral. Petrol. 2004, 80, 45-57. [CrossRef]

70. Sunder Raju, P.V. Textural and compositional relationships of rutile and chromite in Sittampundi anorthosite complex, Tamil Nadu. J. Geol. Soc. India 2013, 81, 709-712. [CrossRef]

71. Lenaz, D.; Adetunji, J.; Rollinson, H. Determination of $\mathrm{Fe}^{3+} / \Sigma \mathrm{Fe}$ ratios in chrome spinels using a combined Mössbauer and single-crystal X-ray approach: Application to chromitites from the mantle section of the Oman ophiolite. Contrib. Mineral. Petrol. 2014, 167, 958. [CrossRef]

72. Lenaz, D.; Andreozzi, G.B.; Bidyananda, M.; Princivalle, F. Oxidation degree of chromite from Indian ophiolites: A crystal chemical and ${ }^{57}$ Fe Mössbauer study. Period. Mineral. 2014, 83, 241-255.

73. Adetunji, J.; Everitt, S.; Rollinson, H. New Mössbauer measurements of $\mathrm{Fe}^{3+} / \Sigma \mathrm{Fe}$ ratios in chromites from the early Proterozoic Bushveld Complex, South Africa. Precambrian Res. 2013, 228, 194-205. [CrossRef]

74. Perinelli, C.; Bosi, F.; Andreozzi, G.B.; Conte, A.M.; Armienti, P. Geothermometric study of Cr-spinels of peridotite mantle xenoliths from Northern Victoria Land (Antarctica). Am. Mineral. 2014, 99, 839-846. [CrossRef]

75. Derbyshire, E.J.; O’Driscoll, B.; Lenaz, D.; Gertisser, R.; Kronz, A. Compositionally heterogeneous podiform chromitite in the Shetland Ophiolite Complex (Scotland): Implications for chromitite petrogenesis and late-stage alteration in the upper mantle portion of a supra-subduction zone ophiolite. Lithos 2013, 162-163, 279-300. [CrossRef]

76. O'Driscoll, B.; Leuthold, J.; Lenaz, D.; Skogby, H.; Day, J.M.D.; Adetunji, J. Melt Percolation, Melt-Rock Reaction and Oxygen Fugacity in Supra-Subduction Zone Mantle and Lower Crust from the Leka Ophiolite Complex, Norway. J. Petrol. 2021, 62, egab078. [CrossRef]

77. Stowe, C.W. Compositions and tectonic settings of chromite deposits through time. Econ. Geol. 1994, 89, 528-546. [CrossRef]

78. Suita, M.T.; Streider, A.J. Cr-spinels from Brazilian mafic-ultramafic complexes: Metamorphic modifications. Int. Geol. Rev. 1996, 38, 245-267. [CrossRef]

79. Candia, M.A.F.; Gaspar, J.C. Chromian spinels in metamorphosed ultramafic rocks from Mangabal I and II complexes, Goias, Brazil. Mineral. Petrol. 1997, 60, 27-40. [CrossRef]

80. Proenza, J.A.; Ortega-Gutierrez, F.; Camprubi, A.; Tritlla, J.; Elias-Herrera, M.; Reyes-Salas, M. Paleozoic serpentinite-enclosed chromitites from Tehuitzingo, (Acatlan complex, southern Mexico): A petrological and mineralogical study. J. S. Am. Earth Sci. 2004, 16, 649-666. [CrossRef]

81. Wood, B.J.; Virgo, D. Upper mantle oxidation state: Ferric iron contents of lherzolite spinels by ${ }^{57}$ Fe Mössbauer spectroscopy and resultant oxygen fugacities. Geochim. Cosmochim. Acta 1989, 53, 1277-1291. [CrossRef]

82. Quintiliani, M.; Andreozzi, G.B.; Graziani, G. $\mathrm{Fe}^{2+}$ and $\mathrm{Fe}^{3+}$ quantification by different approaches and $f \mathrm{O}_{2}$ estimation for Albanian Cr-spinels. Am. Mineral. 2006, 91, 907-916. [CrossRef] 